\title{
Biological consequences of marine pollution with special reference to the North Sea fisheries
}

\author{
Pieter KorRinga \\ Netherlands Institute for Fishery Investigations, IJmuiden, Netberlands
}

\begin{abstract}
KURZFASSUNG: Biologische Konsequenzen der Meerwasserverschmutzung unter besonderer Berücksichtigung der Nordseefischerei. Obwohl das Gesamtvolumen der Ozeane erheblich größer ist als der Süßwasservorrat der Welt, so kann doch das hemmungslose Einbringen von Haus- und Industrieabwässern in das Meer zu schädlichen Folgen für den Bestand der Meeresflora und -fauna führen. Besonders anfällig sind die Küstengewässer, da diese of die Ernährungsgrundlage für viele Nutzfische bieten und zudem dort Austern und Miesmuscheln gezüchtet werden. Aus wirtschaftichen Gründen erfolgt andererseits das Verklappen von $\mathrm{Ab}$ fall und Unrat vorzugsweise dicht unter der Küste. Schädliche Wirkungen können erfolgen durch Bakterien- und Virusinfektionen, durch biologische Akkumulation von Schwermetallen und von Schädlingsbekämpfungsmitteln (unter ihnen besonders chlorhaltige Kohlenwasserstoffe), durch petrochemische Produkte, wodurch übler Geschmack bei Fischen und Muscheln hervorgerufen wird, und durch eine allgemeine Eutrophierung, die zu einer Vermehrung von unerwünschtem Plankton führen kann.
\end{abstract}

\section{INTRODUCTION}

Direct transportation to the sea of waste products is either already begun with, or at least planned, by many countries facing the sea. The former firm belief that open waters, such as lakes and rivers, would be able to accept and to mineralize all man's waste products is badly shaken in our time. First, stagnant waters became grossly polluted. In a later phase even the rivers gave reason for serious concern. At one time there was clean water, rich in fish, among which the valuable salmon occurred. Nowadays dark-coloured, evil-smelling water, practically devoid of fish-life, is found.

In an effort to prevent further deterioration of the river water and, if at all possible, to restore the former good quality of the water in canals, lakes, and streams, despite the rapid industrial development, one proceeds now to discharge liquid waste directly into the sea. This is done either through pipelines or by pumping it overboard from a tanker. It should also be noted that a tendency to locate new industrial plants at the border of the sea is unmistakable.

It is assumed that the sea, with its gigantic volume as compared with that of all the fresh water combined, has such an enormous capacity to receive and to mineralize waste products, that deleterious effects are hardly to be feared. Waves, tides, and sea currents are supposed to see to a rapid dispersion of the discharged waste. Further 
reasoning is that the microbiological mineralization will set free carbon-dioxide, phosphates, nitrates, and a variety of other ions, which will lead to increasing fertility of the sea, and thus to a higher primary production, and ultimately to greater yields of the fishery.

Considering the total volume of even a shallow sea as the North Sea we arrive at some $54,000 \mathrm{~km}^{3}$ if we take the North Sea up to $61^{\circ} \mathrm{N}$. L. Therefore, dumping of 54,000 tons of any material into it, perfectly distributed, would mean a concentration of 1 microgram per liter; a concentration so low that hardly any effect is conceivable, even when truly poisonous products are under consideration. For, even if the material discharged cannot easily be broken down microbiologically, gradual accumulation is hardly conceivable in the North Sea, since flushing by water of the Atlantic Ocean sees to an annual displacement of some $23,000 \mathrm{~km}^{3}$ of North Sea water. This reasoning tries to make clear how attractive waste disposal in the sea will be.

A case of clandestine dumping of copper sulphate on the Dutch beach near Noordwijk (Roskam 1965, 1966) clearly demonstrated that - despite waves, tides, and currents - dispersion of waste discharged into a rather narrow coastal strip of water is quite a slow process. In two weeks time the tides had moved the poisonous body of water, killing both fish and invertebrates, northerly along the coast to the entrance of the Waddenzee. It had not yet been diluted as much as 5 times in that span (Fig. 1). Slight differences in water temperature and salinity apparently preclude a rapid mixing of the coastal waters with those further offshore. Fortunately, strong winds sprang up shortly after, seeing to a more rapid dilution of the copper. The mussels in the western section of the Waddenzee had at that time just begun to die off, but the most important mussel concentrations on the plots further east escaped from annihilation, which could have led to a damage of millions of guilders.

This simple, well-documented case should teach us that a thorough knowledge of zonation and current patterns is a prerequisite if one plans to dispose waste in a given coastal section of the sea. It should be taken into consideration that a polyhaline firth such as the Oosterschelde in the southwest of the Netherlands, and above all well sheltered areas such as the Waddenzee along the Dutch, German, and Danish coasts, are not only of importance for shellfish farming, but are also very important nursery grounds for various species of fish and for the juvenile shrimps. The adult fishes and shrimps, which constitute further offshore important fishery resources, have often spent their early youth on these indispensible nursery grounds, where a great abundance of the right type of food for the young stages is found. Deterioration of the nursery grounds may in due course very well lead to deleterious effects on the stocks of adult fish further offshore. Such a deterioration can easily be brought about by influx of waste, even if this waste is of a non-toxic nature. Excess of organic matter can lead to profound quantitative changes in the fauna inhabiting the superficial layers of the bottom in a shallow sea like the Waddenzee. It leads to a decline in the number of species through disappearance of the more vulnerable organisms (PEArson 1966). Though the total biomass may increase under such conditions, juvenile fishes and shrimps may no longer find their favourite food. Engineering works and waste disposal affecting the nursery grounds should therefore be planned with the utmost care.

As far as the North Sea is concerned one should bear in mind that observations 


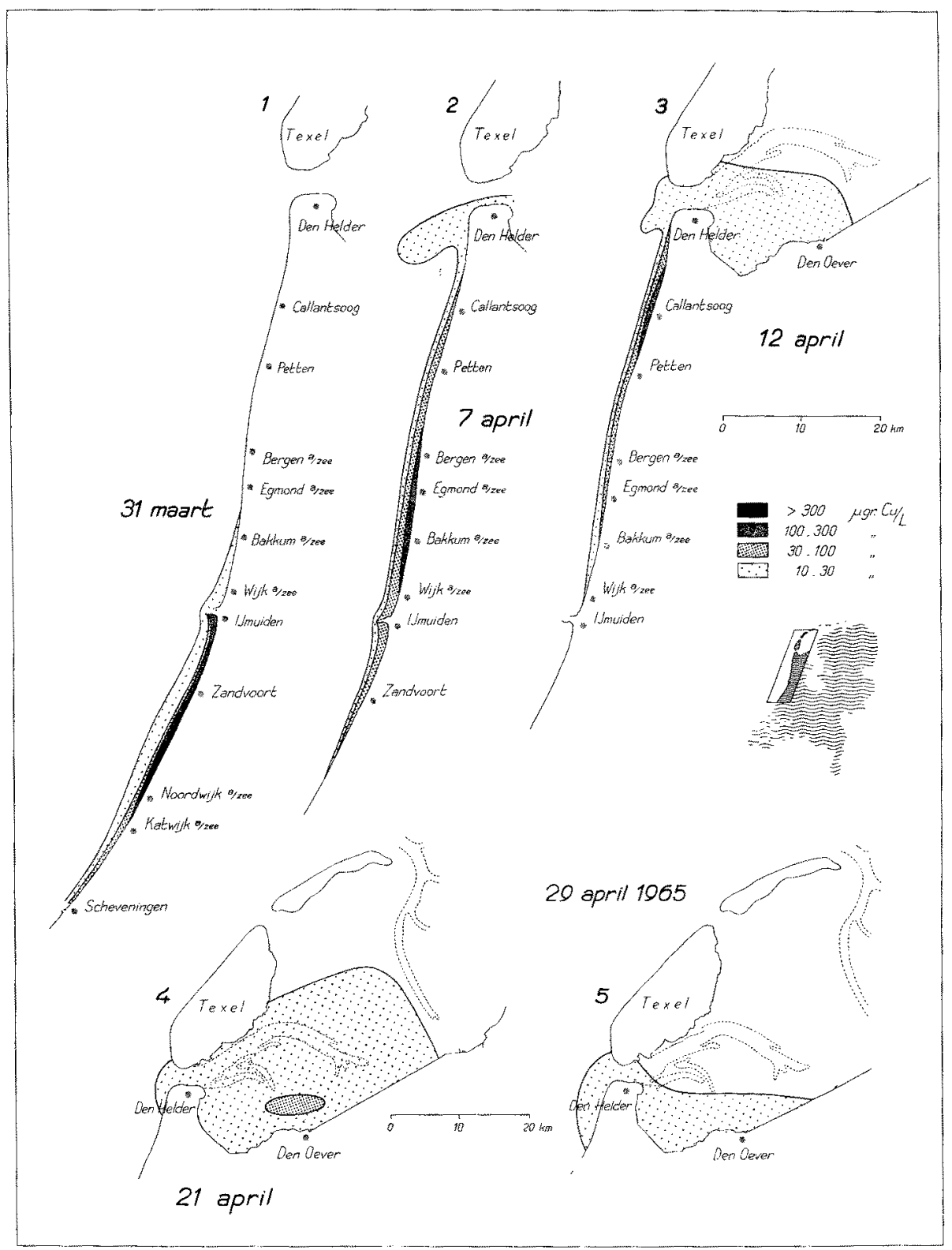

Fig. 1: Copper poisoning on the Dutch coast in the period March to April, 1965. (After Roskam 1965)

on temperature, salinity, plankton, and currents have taught us that its water masses are not at all homogeneous. LaEvastu (1960) informs us that one should distinguish several different sections in the North Sea (Fig, 2). A rather narrow strip of continen- 
tal water, characterized by a somewhat lower salinity, is found along the coastline of Belgium and the Netherlands. This water is roughly bordered by the $25 \mathrm{~m}$ depth line and fans out into the German Bight further north. It is this continental water body, holding only some $600 \mathrm{~km}^{3}$ of water, which has to receive most of the waste from the continental countries facing the North Sea. Since the river Rhine also pours its

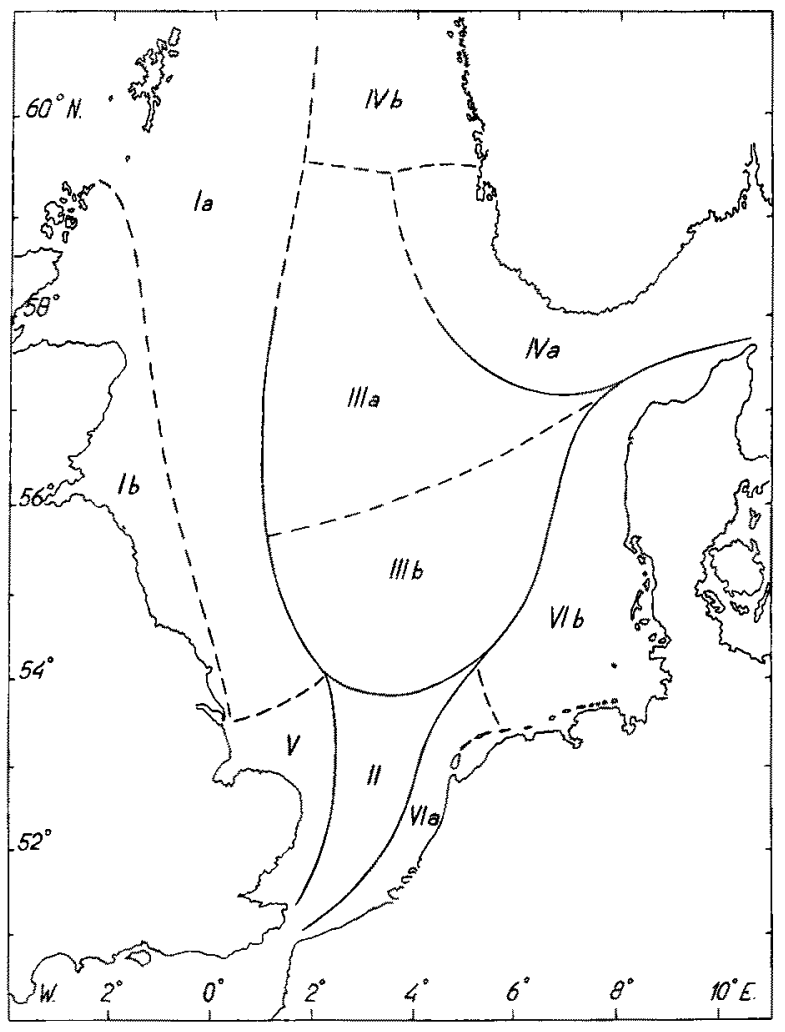

Fig. 2: Biological water masses of the North Sea according to plankton indicator species. (Ia) North Atlantic water, (Ib) Scottish coast water, (II) English Channel water, (IIIa) Central North Sea water North, (IIIb) Central North Sea water South, (IV) Skagerrak water, (V) English coast water, (VIa) Continental water Flemish coast, (VIb) Continental water German Bight. (After LaEvastu 1960)

annual $70 \mathrm{~km}^{3}$ of polluted water into this very section, one should survey the future development with the greatest caution. It are not the accidental calamities but the general trends, the stealthy deterioration of environmental conditions in sections of the sea of vital importance for its living resources, which count most.

To obtain a good idea of the hazards of marine pollution it is necessary to distinguish the effects of various categories of waste. Domestic sewage gives rise to hazards and problems other than waste products from the chemical and petrochemical industry. 


\title{
CATEGORIES OF POLLUTANTS AND THEIR CONSEQUENCES
}

\author{
Domestic sewage and liquid waste produced in processing \\ products of agriculture and animal husbandry
}

\section{Microbial contamination}

Domestic sewage always constitutes a potential hazard, since it contains among other contagious matter, always a fair amount of faecal material. The general practice is to use the number of $E$. coli per given volume of water as indicator for contamination with faecal material. Modern apparatus makes it possible to cultivate and count only the thermo-tolerant type of $E$. coli, which procedure gives less reason for bias than just counting all the $E$. colis in a water sample. Coli in itself does not constitute the danger in water polluted by domestic sewage, but rather the accidental presence of germs causing such diseases as typhoid fever, of viruses such as those causing hepatitis and polio, of a variety of streptococs, staphylococs and yeasts responsible for skin diseases. Bathing in water contaminated by domestic sewage is therefore a potential health hazard.

Direct contamination of the intestinal tract and skin can be the result of bathing in diluted domestic sewage, this not only in fresh water, but also in the sea. The fishery is, however, concerned with indirect contamination. Marine organisms filtering water in search of food and oxygen have a bad reputation as accumulators of dangerous germs from diluted domestic sewage. Consumption of raw shellfish such as oysters, mussels and clams, grown or stored in polluted sea-water, can easily lead to outbreaks of typhoid fever and some other diseases. There is a vast literature on the salubrity of shellfish. The most notorious case was the outbreak of typhoid fever following mayoral banquets in England in the beginning of this century, which led to a serious crisis in the European oyster trade. In due course rigid sanitary control saw to efficacious protection of the shellfish consumers in many countries, which fully restored the confidence in these products. Here too $E$. coli is used as an indicator of contamination. MaziÈres (1963) gives an excellent review of the sanitary control of shellfish. Not only tyhoid fever is a potential danger here but also a virus disease like hepatitis, as recorded in the papers of Roos (1956) and LindBERG-Broman (1956), is nowadays duly taken into account.

Pollution by domestic sewage forced oyster and mussel farmers in many countries to abandon otherwise productive grounds. Oysters from slightly polluted beds have to undergo a prolonged quarantine sojourn on clean beds before they are permitted in the storage basins. Storage basins in polluted zones were closed on instruction of sanitary control officers. Others had to be equipped with suitable purification apparatus so that water and shellfish in such basins could be sterilized with the aid of chlorine, ozone, or ultraviolet light. Peculiarly enough, the shellfish farmers and dealers have usually taken this loss of ground through pollution, and all the expenses to be made for purification of their products, for granted. It was as if any city or industrial plant had officially the right to discharge all their waste indiscriminately into the open water, irrespective of possible damage done to existing industries, such as shellfish 
farming, using the same water as a natural resource. I wonder whether this should be considered as correct from the legal point of view and whether any city or industry really has the right to destroy valuable natural resources by discharging sewage. However this may be, countries producing shellfish for home consumption and exportation are faced with the problem of how to avoid further deterioration of their shellfish resources and how to ensure a continuous high level of cleanliness of their shellfish. It is not sufficient that mussels or oysters on the beds are under normal weather conditions free from pollution. A sound industry cannot accept that its sales can be interrupted by incidental spells of contamination brought about by exceptional weather conditons. Certificates of cleanliness can only be given for batches of shellfish from grounds which are never influenced by domestic sewage or which have passed efficacious purification plants.

A careful study of possible effects on shellfish beds or storage basins is a prerequisite for all new projects envisaging discharge of liquid waste into the marine environment. Furthermore, control of already existing pollution of shellfish beds should be strived after.

\section{Eutrophication}

A variety of micro-organisms sees to the bio-degradation of all organic matter not contained in living organisms. This process takes place on land, in fresh water, and in sea. Not all types of organic matter are readily mineralized, the aromatic compounds as a rule considerably slower than the aliphatic. Factors like water temperature and the amount of suspended matter play an important part in this, the latter since most bacteria usually operate best on some substratum or other. Among the products of bio-degradation are phosphates, nitrates, carbon-dioxide and other ions. These can, in the presence of sunlight, directly be used by plants, including phytoplankton-organisms, to build up carbohydrates, proteins, and fats required for their own growth and reproduction. Mineralization of organic matter discharged into the sea can therefore lead to increased fertility of the sea water, and hence to a greater primary and secondary production. This process is known as eutrophication and is usually thought of in terms of a positive factor in nature.

In $\mathrm{fresh}$ water eutrophication, for instance caused by discharge of the clear effluent of sewage purification plants, can lead to exhuberant growth of aquatic plants. This can be either excessive development of phytoplankton organisms such as flagellates, diatoms, and Cyanophycaea, the so- called water-blooms, or, in shallow water, to mass-development of demersal vascular plants, clogging the waterways. In both cases the natural equilibrium is adversely affected. Periodic mass-mortality of the plants may lead to oxygen depletion, offensive odours associated with decomposition, and fish mortality. In several cases the water-blooms as such are toxic to fish, birds, mammals, and other animals (GorHAM 1962).

In sea water very similar phenomena can occur. Among the many observations I made myself in the Dutch oyster district, the Oosterschelde, some are relative to development and settling of oyster larvae. In the easternmost section of the Ooster- 
schelde the city of Bergen op Zoom discharges its domestic waste. Tides see to a rapid dispersal and micro-organisms to mineralization. At some distance from the harbour the water in summer is rather clear and rich in oxygen, whereas a multitude of small phytoplankton organisms, predominantly flagellates, causes a greenish colour of the water. Further away from the area of pollution flagellates are considerably less numerous. Oyster larvae are carried by the tidal currents to every section of the Basin of the Oosterschelde. Peculiarly enough, settling of oyster larvae can only be observed locally. Even when sufficient amounts of collector material are presented and environmental factors are apparently favourable, oyster larvae fail to settle in many a site. Observations in the easternmost section of the Oosterschelde, including the Eendracht (the water between the island of Tholen and the Brabantian mainland), demonstrated that oyster larvae born further west do arrive in that greenish water but that they sooner or later develop symptoms of ill health. They lose their attractive natural pigmentation, then develop a hyaline vesica, and finally desintegrate. Temperature, salinity, oxygen level and $\mathrm{pH}$ apparantly leaving nothing to be desired, I blame the numerous flagellates for creating conditions detrimental to the delicate oyster larvae. Field and laboratory observations have demonstrated that too rich a phytoplankton, especially too dense a vegetation of flagellates, can create toxic conditions for a variety of sensitive organisms. For this reason I have pleaded in the Council of State against a project involving a considerable increase of organic waste - in itself non-toxic - to be discharged into the Oosterschelde at Bergen op Zoom.

Similar experience has been gained elsewhere. Extensive oyster areas in Long Island Sound deteriorated, especially those in Great South Bay. Settling of oyster spat, once so profuse, stayed away, but ultimately even the adult oysters failed to grow and fatten there. Eutrophication, to be traced to an increment in the number of duck farms on the coast, leading to excessive phytoplankton blooms, had to be blamed for this (REDFIELD 1952). Sites where a profuse settling of oyster spat can be expected regularly, due to a rare combination of environmental conditons, deserve careful protection, for a good production of oyster spat is the basis for remunerative oyster farming.

A special type of plankton blooms leading to toxic conditions of the water is known as red tide. Dinoflagellates, especially of the genus Gonyaulax, are to be blamed for this. Red tide is usually associated with water extremely rich in nutrients, especially in phosphates, for which phenomenon upwelling can be the cause (GalTsork 1948). Though reports on outbreaks of red tide usually come from semi-tropical areas, this does by no means prove that the temperate regions have nothing to fear from plankton organisms producing metabolites so poisonous that shellfish become dangerous to eat, and that fishes eventually die off on a large scale. Events on both the Pacific and the Atlantic coasts of Canada and the United States sound a warning. In Europe several cases of paralytic poisoning after consumption of shellfish, to be traced to dinoflagellate blooms, have been recorded. In all cases it concerns mussels collected in very eutrophic harbour areas. Very well documented is the 1937 red tide explosion in the canal Brugge-Zeebrugge, leading to several casualties by consumption of mussels collected there (Koch 1938, 1939).

For a long time shellfish experts and sanitary control officers in western Europe 
have assumed that mussels and oysters grown in large bodies of sea water along the European west coast would never give rise to cases of paralytic poisoning to be traced to excessive development of dinoflagellates. The summer of 1961 taught us (KorRrngA \& Roskam 1961), however, that dinoflagellates can, here too, give rise to trouble for the shellfish consumer. Gastro-intestinal disorders after consumption of boiled or fried mussels could be traced to a water-bloom of the dinoflagellate Prorocentrum micans. A real cloud of Prorocentrum made its way along the coast from Ostend to Zealand, to arrive in due course in the Waddenzee further north, rendering mussels in the western, non-polluted, sections of Westerschelde, Oosterschelde, Grevelingen, and Waddenzee, in this order, dangerous for the consumer. Experiments with rats confirmed that Prorocentrum was to blame for the gastro-intestinal symptoms.

Though Prorocentrum micans is a regular denizen of the North Sea, a waterbloom of this species producing the effects described above had not been recorded before. Water-blooms of dinoflagellates can be expected in very eutrophic water under special hydrographical conditions. The possibility that the increasing discharge of waste in the coastal waters might have had something to do with the Prorocentrum bloom cannot be denied. The charts presented by Johnston \& Jones (1965) demonstrate clearly how high the nutrient level in the coastal water is. It will be good to keep an eye on Prorocentrum's behaviour in all regions where molluscan shellfish is collected. It has already been recorded that dinoflagellate blooms do occur in the polluted Oslo-fjord in summer (BøHL 1965), and that warnings have been given by the Norwegian authorities against harvesting mussels for consumption in that season. Of special concern should be the fact that, peculiarly enough, the Prorocentrum toxin is apparently not everywhere of exactly the same character. Portuguese scientists (PINTo \& Silva 1956, Silva 1959) hold Prorocentrum micans responsible for cases of paralytic poisoning, sometimes leading to death, after consumption of cockles (Cardium edule) from the lagoon of Obidos. Other very severe cases traced to Prorocentrum blooms are reported from Japan (Nakazima 1965). Here too, it concerns shellfish taken from an area where eutrophication can very well have been the primary cause of development of the Prorocentrum bloom.

The North Sea is renowned for its rich fishery resources. Are not the rivers Rhine, Thames, Scheldt, Weser and Elbe contributing materially to the fertility and productivity of the North Sea? They certainly do, but I personally do not believe that the fish stocks would be affected noticeably if one should manage to reduce the nutrient influx from that source drastically. I rather assume that the productivity of the North Sea should, first of all, be explained in terms of biological accumulation of organic matter by the benthos organisms, an accumulation against a gradient, from the Atlantic water which pours into the North Sea in such great quantities. In its turn the bottom fauna of the Waddenzee does the same thing with the North Sea water which flows into it with the tides.

If we further consider that the growth rate of our most important food fishes is now not noticeably better than it was in the years immediately after termination of World War II, we have to conclude that food is evidently not the limiting factor in the growth rate of fish in the North Sea. A far greater number of fishes than live now in the North Sea could find a sufficient amount of food for an optimal growth. This 
means that there is, from the fisheries point of view, virtually no reason at all to welcome an increasing influx of waste into the North Sea.

\section{Industrial sewage}

Besides the domestic sewage, including the waste from processing agricultural and animal husbandy products, there is a growing amount of waste from the chemical and petrochemical industries. For obvious reasons the industry prefers to discharge liquid and solid waste with a minimum of costs, if possible in the rivers or in the sea. Since several waste products of the chemical industry are not liable to a rapid biodegradation one should, if one wants to obtain a good insight, not lump them together with the domestic waste. Terms like "biological oxygen demand" and "population equivalent", however useful in the study of domestic waste, should be avoided here. Not only is it necessary to deal separately with chemical and petrochemical waste products, but even among those their effect on the natural resources can be of such a different nature that a thorough discrimination between the various categories of chemical waste is a prerequisite in studying the overall effect on the living resources of the sea.

Of the more predominant categories of danger for or damage to the marine habitat some examples are given below:

\section{Heavy metals}

That heavy metals may constitute a hazard to marine life is well known. In general one can say that special caution is required when it concerns discharge into the sea of elements which occur only in minute amounts in natural sea water, and this especially for elements which play a part in biological processes. It are especially the filter-feeding invertebrates, and among those particularly species collecting calcium ions for the construction of their shells, which are renowned biological accumulators of heavy metals. It is not exceptional to find per gram of organism 10,000 to 100,000 times the amount of metal occurring in one gram of natural sea water. Some invertebrates manage to deposite certain metals in inoffensive form somewhere in their body tissues, this especially when they cannot avoid accumulating those in their search for calcium. Oysters are renowned for their accumulation of copper, iron, manganese and zinc, whereas Ascidians are for some reason great accumulators of vanadium. When sea water contains a little more copper than usual, the copper content in oysters may reach an alarming level. Alarming not for the oyster, which can store it in its leucocytes in its connective tissue, but for the oyster eater. A green-blue discoloration of the tissues sounds a warning: such oysters are unpalatable. The harsh flavour makes its consumption most unattractive, so that the consumers' health will not be endangered. It takes a very long time before the oyster, sojourning in pure sea water, gets rid of excess copper. Very different is the reaction of another bivalve, the mussel, Mytilus edulis. As stated in the introduction of this paper, mussels can easily be killed when 
unusual amounts of copper occur in the sea water surrounding them, but as soon as normal conditions are restored, they rapidly lose the excess copper again.

More dangerous for the consumer is accumulation of metals which do not affect the flavour of shellfish as much as copper does. A mysterious disease, called the Minamata disease, had many victims in Japan. It could be traced to consumption of the mollusc Hormomya mutabilis, collected in Minamata Bay. Allergy for shellfish, bacteriological or virological contamination, nor poisonous plankton could be held responsible for this. Autopsies revealed affection of the liver and the presence of mercury. It turned out that a discharge of organic mercury and subsequent accumulation of it in the body the shellfish was the cause of the Minamata disease (IRUKayama et al. 1961). Here too the molluscs had been able to store the excess mercury in their bodies in such a way that they avoided being killed themselves. The real danger comes one step further in the food chain.

Both the directly poisonous action of heavy metals on marine organisms and their possible biological accumulation should be taken into account in any project planning their discharge into the sea.

That marine organisms are so vulnerable in this respect could perhaps be explained in terms of the remarkable chemical constancy of the water in the oceans throughout the realm of time, this in sharp contrast with the fresh water. In the course of evolution the marine organisms have never faced the necessity to defend themselves against fluctuations in abundance of a great number of chemical components of the sea water. A noticeable increase in concentration of one of these elements, to be expected especially in elements which are of rare occurrence in natural sea water, may, in case this element is of biological importance, easily lead to a phenomenon which could best be described as "biochemical inflation". This can lead to a premature death of the organisms or to biological accumulation, which in its turn may give trouble further on in the food chain.

\section{Petrochemical waste products}

Petrochemical waste products are usually not of a very poisonous character in diluted state. Nevertheless their discharge is a serious reason for concern. This not only for bathing resorts, aware of the value of their amenities, but also for the fishery. Fish are not readily killed by traces of petrochemical waste products, but is happens too often that such a waste leads to development of a most unpleasant flavour in fish and shellfish. Phenols and related products are notorious in this respect. It should be taken into account that an offensive flavour in certain batches of fish or shellfish constitutes no hazard for human health, but that it can have catastrophical effects on the market, since it is extremely difficult to prevent that such off-flavoured fish is landed. Considerable financial losses in the fishing industry can be ascribed to this type of pollution, because it affects psychologically potential buyers of fish. The fish sales on the Parisian market dropped to about half their normal value in the period the "TorreyCanyon" was in the news, irrespective of the quality of the fish offered for sale.

An additional hazard for the living resources of the sea is brought about by frantic efforts to avoid stranding of floating masses of crude oil. As long as the oil floats, 
the hazards for fish and fish food are limited, but when emulsified, direct contact is feasible. Often the emulsifiers poured on the oil are far more poisonous for marine organisms of any description than the oil itself. In this respect attention should be drawn to the excellent results French technicians recently obtained with "craie de Champagne", chalk mixed with $1 \%$ of a stearate, which evidently furthers microbiological degradation of the oil.

\section{Pesticides}

Pesticides should also be mentioned as a category of notorious products, discharge of which should never be allowed in the sea. Chlorinated hydrocarbons have a very bad reputation. Catastrophes traceable to pesticides are well known from the land and from the fresh water. Therefore the tendency is growing to bring waste containing such products, or even the products themselves when there is no ready market for them, to the marine environment. Requests for permission to dump or discharge waste of this nature into the sea come in more frequently than ever before, especially since some countries make it virtually impossible to dispose of these dangerous products in another way. To keep this highly poisonous material away from our fishery resources we will need an international convention for prevention of the pollution of the sea and a rigid international control system.

Part of the pesticides comes almost inevitably into the sea with the run-off from the land. Since many types of pesticides are not liable to rapid biodegradation or chemical breakdown a variety of marine organisms will come into contact with them. Insecticides will, as a rule, affect crustaceans, among them copepodes, an important link in many a food chain, since these are rather closely related to insects. It has been observed already that a variety of crustaceans, as well as representatives of other groups, contain in their body fats alarming quantities of chlorinated hydrocarbons. Such organisms constitute a serious hazard for their predators, in whose digestive systems poisonous products are set free, sometimes in lethal quatities. Somewhere in the food chain death may strike. It is very difficult to measure how many zooplankton organisms, fish larvae included, in our coastal waters are wiped out by pesticides, but the effect of some accidental contaminations with pesticides teach us a lesson. A batch of the chlorinated hydrocarbon "telodrin" was accidentally discharged in the Rhine estuary some time ago. It made its way into the coastal area to arrive in due course in the Waddenzee, following the same path as the copper sulphate in Figure 1. Nobody investigated the effect on zooplankton, benthos and fishes, but it has been demonstrated that the virtual annihilation of Sandvich terns (Sterna sandvicensis) from the world-famous populous rookery on the little island of Griend, situated in the Dutch Waddenzee, had to be ascribed to this very product (KoEMAN et al. 1967). I wonder whether observations that cold winters lead to better recruitment of the brown shrimp in the coastal waters of the Netherlands (BonDEke 1967) should not be explained in terms of poor quality of the water closely inshore. The lower the water temperature in winter, the further offshore the egg-bearing female shrimps migrate. It does not seem impossible that pesticides play some part in this. 
Next to heavy metals, pesticides require the greatest caution in reglementing their disposal. Incineration will, as a rule, be the best choice; as a good second choice should be considered dumping in barrels on a well-selected site of the ocean floor, far away from the continental shelf.

\section{Synthetic detergents}

The toxicity of some synthetic detergents and soaps has been tested on marine fishes. Under a concentration of 5 p.p.m. no harmful effects have been observed (EIsler 1965, Eisler \& Deuel 1965, MarchetTi 1965). We should, however, bear in mind MARCHETTI's observation that "there are in the natural aquatic medium innumerable animal and vegetable organisms at different stages of development so sensitive that they are damaged by concentrations much lower than those evaluated on these basis of the laboratory experiments completed in special conditions and with adult animals" (MARchetTi 1965).

Since degradation of several detergents sets free noticeable quantities of phosphates, discharge of these products can lead to eutrophication and therefore, under special conditions, to secondary effects deleterious for the natural resources of the sea.

Detergents and soaps are known for their lowering effect on the surface tension, but it is still insufficiently known in how far this may influence plankton organisms and other sensitive creatures in the dilutions to be expected in the marine environment. It should also be considered that detergents, through their emulsifying properties, aggravate the effect of crude oil and similar products on the aquatic fauna.

\section{Radio-active waste}

Disposal of radio-active waste in sea is a problem of serious concern. In this special case, however, scientific investigations on the effects of such a discharge precede the actual discharge itself. Many reports have already appeared on this subject. Among those the results obtained by the combined efforts of Euratom and C.N.E.N. in the Fiascherino laboratory (BERNHARD 1967) are of special interest for those concerned with the European seas and their resources. Careful monitoring sees to it that ill effects are prevented. As in the case of heavy metals, special attention should be paid to the discharge of those elements of biological importance which are of rare occurrence in natural sea water. Of course, the half-life span of the radio-active elements to be discharged is also a factor to be taken into account. Discharge of radioactive waste should definitely not be expressed in the number of Curies per unit of time. It is the character of the radio-active element which counts first. In discharging radio-active waste not only the biological effects, but also the psychological factor, the mistrust of the fish consumer, should be taken into account, especially in countries which are exporting fish and shellfish. 


\section{DISCUSSION}

The rapidly expanding industry will lead to discharge of greater and greater quantities of waste of ever increasing variety into the marine environment, either through pipelines or by means of tankers and other ships. It is impossible and also unnecessary, to prohibit complete discharge of waste into the sea. Great care is, however, required. The waste products to be discharged should be studied carefully as to their chemical composition and as to their effects on the microscopical and macroscopical denizens of the sea. Special attention should be paid to the coastal areas which often are the indispensable nursery grounds for fish and shellfish. Deterioration of nursery grounds of vital importance can have a disastrous effect on the fish stocks further offshore.

Careful studies should be devoted to bacteriological contamination, viruses included, and to products poisonous for marine organisms, especially those which are accumulated biologically. Heavy metals and pesticides require the greatest caution. Discharge of products affecting the flavour of fish and shellfish as well as of radioactive waste can even in very small quantities exert an ill effect on the fish market.

Careful discrimination between the many waste products is a necessity. It will be found that some can be discharged without producing any ill effect on the marine environment, but it will always be good to discharge the material some distance offshore. Other products should be transported over greater distances, by preference beyond the continental shelf. Others still, should be packed in drums or barrels to be dumped on a carefully selected site of the floor of the ocean, at great depth. But if man does not want to deteriorate the marine environment, one of his favourite resorts and important source of foods rich in proteins, he should carefully prevent discharge of products which are labelled as very dangerous. Such products should be incinerated or treated in another way to render them inoffensive. The costs of such a treatment will certainly be small compared with the wide-spread deleterious effects their discharge in the sea can have.

\section{SUMMARY}

1. A case of copper pollution on the Dutch coast is used to demonstrate that waste disposal in inshore waters can easily lead to damage to the living resources of the sea, since dilution is under such conditions a much slower process than is usually assumed.

2. Pollution by domestic sewage, its direct hazards for human health, and its contaminating effect on shellfish, is discussed. Next to these direct and indirect health hazards, discharge of domestic waste may lead to eutrophication, which in its turn can contribute to the development of plankton blooms producing truly poisonous metabolites. Some examples of eutrophication of the marine environment are given.

3. Of the industrial waste, examples are given which clearly demonstrate how dangerous discharge of heavy metals and pesticides can be, also in the marine environ- 
ment. Possible effects of petrochemical waste products and of synthetic detergents and soaps are discussed.

4. Radio-active waste disposal in sea is more carefully studied and monitored than disposal of other types of waste.

5. The increasing quantity and variety of industrial waste is a reason for serious concern. Careful discrimination between the many products is advocated and discharge far offshore is advised for certain categories of pollutants. Pesticides and other very dangerous products should never be admitted in the shallow sea areas, so important as nursery grounds for the fishery resources.

\section{LITERATURE CITED}

Bernhard, M., 1967. Studies on the radioactive contamination of the sea. Annual report 1965. European Atomic Energy Community (Euratom), Comitato Nazionale per l'Energia Nucleare, Fiascherino, La Spezia, Italy, 29 pp. (CNEN Rep. No RT/BIO <66>28.)

Boddeke, R., 1967. 1967 een schraal garnalenjaar. Visserij 20, 167-169.

BørLe, B., 1965. Undersøkelser av blăskjell (Mytilus edulis L.) i Oslofjorden. Fiskets Gang $\mathbf{5 1}$, 388-394.

EIsler, R., 1965. Some effects of a synthetic detergent on estuarine fishes. Trans. Am. Fish. Soc. 94, 26-31.

- \& Deuel, D. G., 1965. Acute toxicity of soaps to estuarine fishes. Progr. Fish Cult. 27, $45-48$.

Galtsofr, P. S., 1948. Red tide, Spec. scient. Rep. U. S. Fish Wildl. Serv. 46, 1-44.

Gorham, P. R., 1962. Toxic water blooms of blue-green algae. In: Biological problems in water pollution. 3rd Seminar, Aug. 13-17, 1962. Ed. by C. M. Tarzwell. U. S. Dept of Health, Education and Welfare, Div. of Water Supply and Pollution Control, Cincinnati, Ohio, 37-43. (Public Health Service Publ. No 999-WP-25.)

Irukayama, K., Kondo, T., KaI, F. \& Fujukx, M., 1961. Origin and causative agent of Minamata disease. Organic mercury compound in fish and shellfish from Minamata Bay. Kumamoto med. J. 14, 157-169.

Johnston, R. \& Jones, P. G. W., 1965. Inorganic nutrients in the North Sea. In: Serial atlas of the marine environment. American Geographical Society, New York, Folio No 11.

Kосн, H. J., 1938. Verlammende vergiftiging door mosselen. Archs Med. soc. Hyg. 9, 796-805.

- 1939. La cause des empoisonnements paralytiques provoqués par les moules. Bull. Ass. fr. Avanc. Sci. 63, 654-657.

KoEman, J. H. [a. o.], 1967. Insecticides as a factor in the mortality of the sandvich tern (Sterna sandvicensis). Meded. Landb Hoogesch Opzoek Stns Gent 32 (in press).

Korringa, P. \& Roskam, R. Th., 1961. An unusual case of mussel poisoning. In: C.M. (Council Meeting) I.C.E.S. (International Council for the Exploration of the Sea) Sect.: Shellfish Committee 49.

Laevastu, T., 1960. Synopsis of information on the oceanography of the North Sea. In: F. A.O. Fisheries Division Project. Food and Agriculture Organization, Rome, No $2(21 / 3)$.

- 1963. Surface water types of the North Sea and their characteristics. In: Serial atlas of the marine environment. American Geographical Society, New York, Folio No 4.

Lindberg-Broman, A. M., 1956. Clinical observations on the so-called Oyster Hepatitis. Svenska Läkartidn. 53, 1003-1009.

Marchetti, R., 1965. Critical review of the effects of synthetic detergents on aquatic life. Stud. Rev. gen. Fish. Coun. Mediterr. 26, 1-32.

Mazières, J., 1963. Les coliformes dans les eaux marines et les huîtres. Application à l'hygiène ostréicole. Revue Trav. Inst. Pêch. marit. 27 (1), 3-110.

Nakazima, M., 1965. Studies on the source of shellfish poison in Lake Hamana. Bull. Jap. Soc, scient. Fish. 31, 198-207; 281-285. 
Pearson, E. A., 1966. A comprehensive study of San Francisco Bay. Ser. Rep. sanit. Engng Lab. Univ. Calif. 65-8, 1-75.

Pinto, J. S. \& Silva, E. S., 1956. The toxicity of Cardium edule L. and its possible relation to the dinoflagellate Prorocentrum micans EHr. Notas Estud. Inst. Biol. mar. Lisb. 12, 1-12.

Redfreld, A., 1952. Report to the towns of Brookhaven and Islip, N. Y. on the hydrography of Great South Bay and Moriches Bay. Oceanographic Institution, Woods Hole, Mass. 80 pp. (Ref. No 52-26)

Roos, B., 1956. Hepatitis epidemic conveyed by oysters. Svenska Läkartidn. 53, 989-1003.

Roskam, R. TH., 1965. A case of copper pollution along the Dutch shore. In: C. M. Council Meeting) I. C. E.S. (International Council for the Exploration of the Sea) Sect. C: Near Northern Seas Committee 44.

- 1966. Kopervergiftiging in zee. Wat. Bodem Lucht 56, 19-23.

Srya, E. S., 1959. Some observations on marine dinoflagellate cultures. Notas Estud. Inst. Biol. mar. Lisb. 21, 1-15.

\section{Discussion following the paper by KORRINGA}

CARRUTHERS: I draw attention to the feature so well documented in your country, the ingoing current "salt-wedge", which is detectable in the Rotterdam Waterway as far as $30 \mathrm{~km}$ from the sea; have you evidence of any discharges heavy enough to sink to the bottom, being spread inland to an appreciable distance?

KORRINGa: Discharge by pipelines is now put in practice at Scheveningen, north of the Rhine estuary, and is planned for a site north of IJmuiden. Tidal currents displace the waste in a northern direction. Therefore the salt-wedges in the Rhine mouth and in the Noordzeekanaal are now not easily transporting waste land-inwards again.

KAYSER: Ergänzend zu der Beobachtung, daß der Dinoflagellat Prorocentrum micans im holländischen Wattenmeer giftige Wasserblüten hervorruft, möchte ich anmerken, daß dieser Flagellat von uns auch in der freien Nordsee in großer Zahl angetroffen wurde. In einem Seegebiet 12 Seemeilen nordwestlich von Helgoland war Prorocentrum micans in der Zeit vom 5. bis 13. September 1967 zahlenmäßig die häufigste Form der Dinoflagellaten neben einer Vielzahl von Diatomeen. Prorocentrum micans kann daher nicht nur als Küstenform, sondern auch als Bewohner der offenen Nordsee angesprochen werden.

Korringa: Prorocentrum micans is of normal occurrence in the North Sea and sometimes even in considerable numbers, but what we are worried about are such explosions that you find in one mussel, more than a thousand little frustules in the intestinal tract, and it is only when there is such a dense bloom that we can expect some ill effects. Again, I want to stress the peculiar fact that evidently poisonous excretes are not produced by every Prorocentrum stock to the same extent and in the same way. I think further investigation in that respect will be most interesting. Thank you for your information.

RHEINHEIMER: Im Zusammenhang mit Ihren Ausführungen über die Infektionsgefahr durch Abwässer für Badende möchte ich auf die Infektionsgefahr durch überfüllte Badestrände hinweisen. Es besteht ja die Tendenz, daß die Kapazitäten der Seebäder von Jahr zu Jahr stark erhöht werden. Dadurch vergrößert sich auch die Gefahr der Ansteckung mit beispielsweise durch Pilze verursachten Hautkrankheiten und anderen Infektionen. Sind hierüber genauere Untersuchungen durchgeführt und Abhilfemaßnahmen erwogen worden?

KoRrINGA: During the discussions in the first meeting of the I. O. C. Working Group on Marine Pollution (Paris, August 1967), Professor J. Brisou, representative of W. H. O., drew attention to the medical hazards of bathing in the sea where sewage is discharged or where too many people concentrate on too limited lengths of beach. Special stress was laid by him on the pollution caused by the thousands enjoying themselves in small boats in inshore waters, especially in areas with limited tidal currents. 